\title{
Contemporary Islamic Calligraphy Learning
}

\author{
Abd. Aziz Ahmad* \\ Department of Fine Arts and Design \\ Makassar State University \\ Makassar, Indonesia \\ *abdaziz.ahmad911@gmail.com
}

\begin{abstract}
Learning Islamic calligraphy has long been taught in Islamic-based schools. Both at the elementary school, middle school, and even college. Generally taught is standard letter Islamic Calligraphy and has a standard formula, also called pure calligraphy which is followed by many khathaths in many Islamic boarding schools and Islamic schools in various parts of the world, such as Naskhi khat, Tsuluts, Pharisees, Diwani, Diwani Jali, Kufi, and Riq'ah. In connection with the "standard" statement of Ibn Muqlah, states that, calligraphy is considered true if it has five criteria: Tawfiyah (right), Itman (complete), Ikmal (perfect), Isyba '(solid), and Irsal (smooth). Even if the category of contemporary calligraphy in the Islamic world has to be established, it will be divided into the following categories: Traditional, Figural, Expressionist, Symbolic, and Abstract, known as calligraphy paintings. In this description the author adds another category, namely Surrealistic calligraphy painting. There are five steps offered in Surrealistic Contemporary Islamic Calligraphy, as follows; make the basic pattern in the form of an infinity line, add a background in the form of fauna, flora or animals, carve Arabic characters, make shading (coloring) and finish. Aesthetically contemporary calligraphy refers to the rules of the creation of contemporary art, and ethically originates from the Qur'an, Al-Hadith, and aphorisms which carry artisticappreciative content to function as a medium of appreciation, on the other hand contain functioning ethical-religious content as a guide as well as a media for da'wah.
\end{abstract}

Keywords-Islamic calligraphy, contemporary, fine art, surrealism

\section{INTRODUCTION}

The contemporary Islamic art that developed in Indonesia, including calligraphy painting, made people surprised and gave rise to various views among Muslim artists, because of its sudden presence in the 70s. Even though it did not appear just like that, but through a long struggle of ideas, it flourished among our artists in recent times, especially since the exhibition of Islamic Calligraphy Art at the MTQ XI 1979 in Semarang and the exhibition at the World Islamic Mass Media Conference I at the Jakarta Senayan Convention Center in early September 1980. More lively after the Contemporary Islamic Calligraphy was one of the fields contested in the Musabaqah Khattil Quran both at the Provincial and National Level MTQ.

Contemporary Islamic calligraphy is a work of art that ignores the standard rules in writing Arabic calligraphy. As is known that since hundreds of years ago Islamic calligraphy has grown rapidly through the skilled hands of Muslim calligraphers. It has reached its peak with the discovery of various types of formulations of standard Islamic calligraphy that it seems difficult to break them. Talking about the standard types of Islamic calligraphy that are considered to have a standard formula there are at least seven types of calligraphy (khat) circulating in the Islamic world including; khat Naskhi, Sulus, Diwani, Diwani Jali, Farisi, Riq'ah, and Kufi. Another type of calligraphy is the development of the "standard" calligraphy. As a small example in writing 'raw' calligraphy, the Naskhi khat type of alif should be as high as five points of the pen used, while for the seven types of Sulus khat. If violated the provision is considered a mistake. It can even be fatal especially in the assessment of the Islamic Calligraphy competition because it has the potential to reduce the value of a work.

In connection with the "standard" statement of Ibn Muqlah (d. $328 \mathrm{H} / 940 \mathrm{M}$ ), states that, new Islamic calligraphy is considered true if it has five criteria [1]:

- Tawfiyah (right), that is by letter must get a swab according to its part, from curvature, cruelty and bending.

- Itman (complete), i.e., each letter must be given a full size, from long, short, thin and thick.

- Ikmal (perfect), that is, each stroke of the line must be in accordance with the beauty of a reasonable form, in the style of upright, supine, twisted and curved.

- Isyba '(solid), that is, every stroke of the line must get a right touch from the pen's eye so that a harmony is formed. Thus, there will be no inequality, one part appears to be too thin or too thick from the other, except in the areas of touch that require it.

- Irsal (fluent), namely scratching the pen quicklyprecisely, not stumbling or being stuck so that it is troublesome, or breaking down in the middle so that the vibration of the hand continues to damage the writing that is being scratched. 
Besides that Ibn Muqlah also contributed to creating a rhombus point as a unit of measure [1]. Then design three forms, namely rhombus point, vertical alif, and circle which are used as the basic formulas for measuring each letter [2].

From various events in Islamic calligraphy competition activities, especially when invited as a Calligraphy Judge Board there are participants (calligraphy painters) who still question what exactly is meant by Contemporary Islamic Calligraphy. Art activities are dynamic and always develop from time to time. To make the definition of contemporary calligraphy certainly experience development. The definition in general is a calligraphy whose expression does not want to be bound by standard rules, both in the writing of Arabic script and the background of the writing, because it is considered to limit their freedom of expression.

Aesthetically contemporary calligraphy refers to the rules of the creation of contemporary art in general and ethically originates from the Qur'an and Al-Hadith, which carry artisticappreciative content that functions as a medium of appreciation, on the other hand contains a functioning ethicalreligious content. as guidance or media of da'wah.

\section{DISCUSSION}

\section{A. Contemporary Calligraphy Pattern}

In the book "Islamic Calligraphy Art" written by D. Sirojuddin AR, that contemporary Islamic calligraphy is a "rebellion" on the pure rules of classical calligraphy [2]. The development is very fast stuffing various media in categories. This school tries to escape the prevalence of khath or pure calligraphy which many khathaths follow in many Islamic boarding schools and colleges, such as Naskhi,

Tsuluts, Farisi, Diwani, Diwani Jali, Kufi, and Riq'ah. Among the characteristics of "offense" which points to evidence of creative freedom that produces different styles can be deduced from the following possibilities:

- Fully stand alone as a painter's distinctive treat, by completely ignoring the pure anatomy of the khat letters. This form is a technical exploration and freedom of expression of the painter.

- It is a combination of the imagination of the painter and the popular pure style. In this section, contemporary works still inherit their traditional forms.

Contemporary style also leads to the tendency of themes, namely two-dimensional or three-dimensional works that present elements of "independently" calligraphy and are based on other elements in aesthetic unity with appearance as expressive, media, and technical styles. The real manifestation of nature in the works is presented through real depictions of landscapes, objects and events.

Certain features of this new style of calligraphy differ from one region to another, but there is no difference that stands out from one region in developing the ancient Islamic art. It does not mean that the work of the calligraphers today does not show a variety of patterns. The diversity of patterns is there, but the diversity of patterns is based more on adaptive variations of influence from the non-Islamic world rather than national characteristics. Even if the category of contemporary calligraphy must be set in the Islamic world, most of the new styles will be divided into the following categories: Traditional, Figural, Expressionist, Symbolic, and Abstract. In this paper the author adds one more category, namely Surrealistic Calligraphy.

\section{B. Traditional Calligraphy}

This traditional calligraphy is produced by contemporary Muslim calligraphers in various styles and writings that have been known for generations of previous calligraphers. The use of the word "traditional" shows art with the traditions of the past khat. Messages that are more emphasized on the beautiful arrangement of letters than displaying calligraphy paintings in the form of natural frames. However, there are also traditional calligraphers that paint calligraphy in foliage patterns or floral motifs and geometric patterns. Based on the above definition, it can be concluded that traditional art is a form of work that contains aesthetic values and clings to tradition. In other words traditional art is an art form that is guided by rules or rules for generations. So in principle, standard style calligraphy is cultivated and modified in such a way as to experience development from the previous style.

\section{Figural Calligraphy}

Contemporary calligraphy is called "figural" because it connects figural motifs with elements of calligraphy through various ways and styles. Figural elements are usually limited to leaf motifs or flowers which are described to be more in line with the abstract nature of Islamic calligraphy. Human or animal figures are usually rarely found in Qur'anic texts written in calligraphy, in the decoration of mosques or madrassas. This last type is more widely used in household appliances. In the figural type, there is often a "fusion" of letters in past and contemporary painting. In designs like this, the letters are extended or shortened, widened and slipped, or broken down by extension of circles, additional signs and other inserts made to correspond to non-calligraphic, geometric, floral, fauna, or human figures. Referring to the term in art, it is called figurative paintings, meaning paintings that display objects, humans, animals and plants, the usual opponents are NonFigurative paintings or Abstract paintings, or works that are formless, intangible. In fine art, abstract according to Susanto means creations which consist of lines, shapes and colors which are completely free from the illusion of forms in nature, but more generally, art in which natural forms it does not function as an object or theme that must be delivered, but as a motive [3]. Abstract art is also called Non-representational or Non-configurative art. 


\section{Expressionist Calligraphy}

Expressionist calligraphy is the third type of contemporary calligraphy in the Islamic world today. This style is related to major developments in Western aesthetics. Although expressionist calligraphers use the "vocabulary" of Islamic artistic heritage, they are far from the standard "calligraphy" of the original calligraphy. In expressionist calligraphy, it is necessary to work on the delivery of emotional, visual, and personal responses to the objects, people or events described. In art, there are those who are called expressionism painters, who are painters who prioritize their own inner outpouring freely. Sometimes inner feelings can be poured out after a long period of heartfelt events have passed. An expressionist painter of Indonesian art maestro Affandi, waited a while to pour out his inner content which he had condemned.

\section{E. Symbolic Calligraphy}

The fourth category of contemporary Islamic calligraphy is called "Symbolic" calligraphy by imposing "unification through a combination of meanings", the role of letters as conveying a message. The proof of this kind of acculturation is very evident in contemporary calligraphy designs that use certain Arabic letters or words as symbols of ideas or ideas that are plagiarized. For example the letter sin is associated with sayf (sword) or sikkin (knife) which is usually juxtaposed together with the depiction of association objects to convey "specific messages". Perhaps this type of letter can be seen in "Sharp Character". For some people, almost all letters can be understood symbolically, even though some others don't agree. This is considered normal because every artist (calligrapher) has a separate concept of work which is used as a reference in pursuing the process of continuous work.

\section{F. Abstract Calligraphy}

The fifth style of contemporary Islamic calligraphy is called "false khat" or "absolute blurred khat" because it shows art patterns that match letters or words but does not contain any meaning that can be attributed to it. By denying the linguistic meaning, the letters only become elements of a pattern and for mere "purposes" of art. Through the use of these changing alphabetic elements, abstract calligraphers use letters as a pattern, not as elements of a message. So, the letter Hijaiyah is used as an element of fine art as well as elements of lines, colors and shapes. Not caring about the legibility of the letter into a word, let alone as a sentence that contains meaning. In terms of the form, it turns out that the letters Hijaiyah have their own character, for example the Alif letter with a standing position signifies firmness, and rigidity. The letter $\mathrm{Ba}$ 'Ta', Tsa and Nun implies a container that can accommodate something, as well as the letter Dal, Dzal indicates the person who is sitting and another example.

\section{G. Surrealistic Calligraphy}

The sixth style which is an addition to the five styles of Contemporary Islamic calligraphy that was previously popularized, namely Surrealistic calligraphy. In the discussion of works of art, the term Surrealism was known, which at first was a movement in literature. This term was put forward by Apollinaire for his 1917 drama. Two years later in 1919, Andre Breton took it to refer to his experiment in spontaneous writing methods. Surrealism relies on the belief in the superior reality and freedom of our associations that have long been abandoned in dream exhaustion, in our automatic thinking without control of our consciousness.

Surrealistic Calligraphy is an alternative in the development of Contemporary Islamic calligraphy [4]. This contemporary Islamic calligraphy was developed by the author (Abd. Aziz Ahmad). With the concept that, in making a calligraphy, especially in writing Arabic scripts, they want to be free and without being bound from a standard Arabic script. As a background, paintings are displayed in forms of animals, fauna and flora whose portrayals are not as common as in their original form. Sometimes it appears in a form that does not refer to the object and sometimes resembles a strange creature. The object of the work, which is most often displayed is the shape of a bird, is used as one example of various creatures created by God Almighty. With hope it can be a reflection for us how God's omnipotence creates a bird that can fly high in space and become a source of inspiration for technocrats to create various types of aircraft. Allah created everything with a specific purpose and purpose and nothing was in vain. Become a source of inspiration in creating various Islamic calligraphy works.

Calligraphy works are categorized as Surrealistic calligraphy because the depiction of birds does not imitate birds in the real world. The shape of the bird that has been distorted and does not match the original shape. Birds that are in fantasy and in the subconscious in dreams. The animal's nature will be the background of the work. With this reason, this type of calligraphy can be categorized as Surrealistic Contemporary Islamic Calligraphy.

\section{H. Abdul Aziz Calligraphy}

Furthermore, the steps taken by Abd. Aziz Ahmad in the process of creating calligraphy, broadly consists of four steps as follows:

1) Making an archetype: It is the basic pattern, which is a pattern that will be a reference and foundation for placing objects to be arranged in a drawing field, this is related to composition. This basic pattern in the form of continuous lines is not interrupted. This line is termed an infinity line or endless line. The technique is to draw circular lines or scratches and twist freely according to taste. With provisions where the scratch begins there will also end. In making a scratch, it needs to be considered is the position of the work to be made, whether the work will be horizontal (horizontal) or the position is vertical or elevated. Examples of infinity lines are as follows (figure 1). 


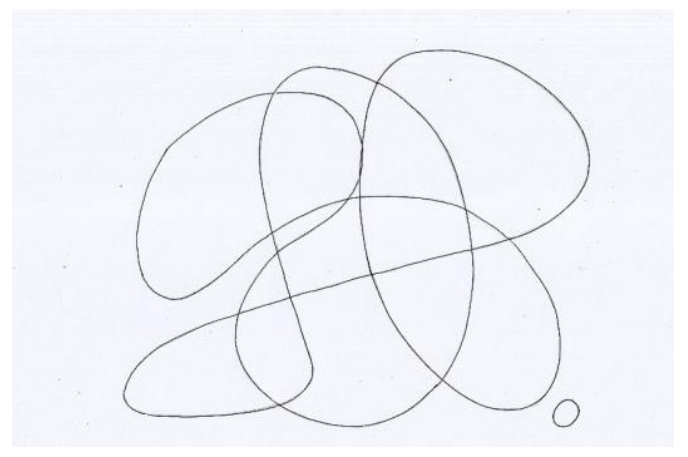

Fig. 1. First step, making the basic pattern of infinity lines. This basic pattern is made using a pencil or may also use color markers pastel if it's a colored work.

2) Creating a painting background: It is intended as an object that is the background of text or writing. While the writings displayed are in the form of quotations from the Holy Qur'an or the hadith of the Prophet or Arabic poems, word and proverbial pearls (Latin script), and also in the form of "Pappaseng", and the advice of our parents in the form of Pappangaja in Lontara Script (Bugis- Makassar script). So the background to the painting is in the form of a form; animals (birds), actually animals by the Director General of Forest Protection and Nature Conservation, 1993 defines as all kinds of animal resources derived from animals that live on land, water and air. The word fauna comes from Latin which has the meaning of animal nature. In Roman mythology, the word fauna can be interpreted as the elder brother of Faunus, which means a good spirit of forest and land. The definition of endemic fauna is all types of animals that live in certain areas. Examples of endemic fauna are native birds from Papua. The native Javanese fauna is one-horned rhinoceros. While the endemic fauna of Sumatra is the Sumatran tiger. Similar to flora, fauna also has geographic names in its use, such as Australian fauna, Asian fauna, and so on. Sometimes, to added form of flora. Flora itself can be interpreted as a group of plants. Endemic flora are various types of plants that live in certain areas, such as the endemic flora of Sumatra (carrion flower), Java (jasmine), Papua (red fruit) and so on. Whereas poultry is a type of livestock that is used for meat and eggs or feathers, for example; chicken, duck, goose, turkey and so on. All of that is a reference in making animals, but the reality is often contrary to reality such as four-legged birds, or horned horses, and so on. In the contemporary calligraphy competition there is a prohibition on highlighting the background of living things that violate the norms of decency, such as images of humans who do not cover genitals, display sadism and so on. On the other hand, sometimes the background is only geometric shapes, circles, triangles, both with a variety of colors or black-and-white works as exemplified in this paper. Creating a painting background can be seen in figure 2 .

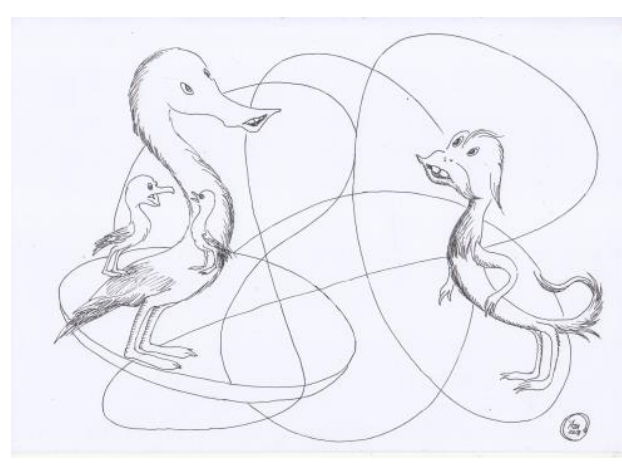

Fig. 2. Second step, making the background of the work in the form fauna, flora, animals, and poultry.

3) Simply calligraphy means beautiful writing: The type of calligraphy that is displayed consists of various Arabic script characters, Latin script and regional characters (BugisMakassar script, Javanese script, Batak, Lampung, etc.). Arabic script or Arabic calligraphy is often called Islamic calligraphy (see figure 3). Even the public's perception that calligraphy is the connotation of Islamic calligraphy. In Islamic calligraphy itself there are various types of letters, among others; Khat Naskhi, Sulus, Diwani, Diwani Jali, Riq'ah, Farisi and Kufi. In addition to various types of khat that have reached the standard and standard stages, there are also types that take the name of the character or the nature of the letter itself. At present the author has recorded a variety of calligraphy characters containing 12 characters, namely: Character of Fire, Water, Sharp, Fat, Skinny, Rope, Bamboo, Folds, Beams, Chess Boards, Leaves, and Fish Characters. Various character letters are found in the book: "The Variety of Islamic Calligraphy Characters: Peeling Out the Complete Calligraphy of Expression". Exemplified in this article Fat Character.

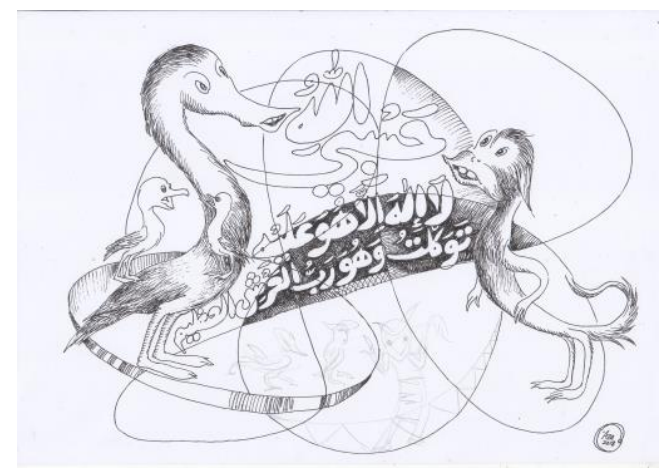

Fig. 3. Third Step: Adding text in the form of holy verses of the Qur'an, Prophetic Hadith, Arabic Poetry, Pribahasa, or Aphorisms in the form of advice and advice. 
4) Shading is pulling small lines parallel or crossing to get a shadow effect: This understanding implies that to get the effect of dark light in a painting should make shading on certain parts. In colored works, by giving a color that is older than the color of the object itself. Followed by the final touch, intended if in the process of work there are still shortcomings, for example there are punctuation marks, one letter or even a syllable that is lacking or the wrong writing can immediately be corrected before the calligraphy works are framed and displayed in the exhibition hall. At this final stage of completion, a calligrapher usually signs his or her initials. Signatures need to be made and include an integral part of the work intended as moral responsibility for the work produced. The position of the signature is usually located at the bottom corner of a work. The shading (coloring) can be seen in figure 4.

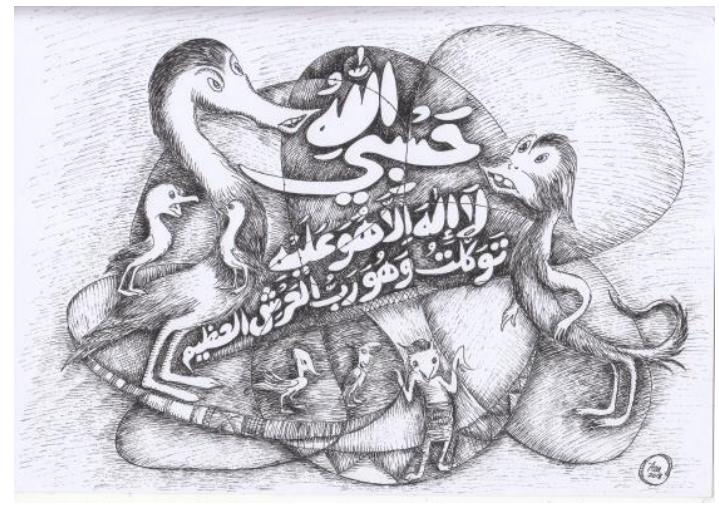

Source: www.azakaligrafi.com [5]

Fig. 4. Fourth Step: Shading (coloring) on certain parts to make the impression of darkness and the final finishing process of the work (finishing touch) This work was made on April 23, 2018. Media: Chinese ink on paper. Size: 21 x $29.7 \mathrm{~cm}$.

Islamic Calligraphy above is quoted from Surah AtTaubah: 129. The translation: "Allah is enough for me, there is no God but Allah. Only to Him do I trust and Allah is Lord the Owner of the great "Throne (Throne)".

\section{CONCLUSION}

In making Contemporary Islamic calligraphy paintings there are several provisions that need to be considered by a calligrapher, among others:

- It is better to look at the material to be written, especially to pay attention to the principles of imlaiyah, especially if it is written in the holy verses of the Koran, because if there is an error in writing, the consequences can be fatal because it can mean something else.

- Islamic calligraphy is part of fine art, so the formulas or elements of artistry also apply to the work of calligraphy. Need to consider in terms of; balance, composition / arrangement of objects, harmony of form / color, unity of forms and themes, rhythm, darkness, proportion, anatomy of letters and so on.

- It takes creativity to create unique forms that give birth to artistic works, which can be pleasing to the eye when viewed.

- There are four steps offered by Abdul Aziz Ahmad in painting Contemporary Islamic calligraphy. The five steps are as follows; make a basic pattern in the form of an infinity line, adding a background in the form of fauna, flora or animals, writing inscriptions (Arabic script), making hatches as finishing (final finishing).

The diversity of patterns from several categories mentioned above, in principle, both want to create a quality work of art, as a form of the expression of aesthetic and Islamic ethics of an artist (calligrapher). A very prominent difference lies in the characteristics that are attempted to be displayed and the media used by each calligraphy artist. In the end the function and purpose of Contemporary Islamic Calligraphy, in addition to being a work of art that will be a media of appreciation for the wider community and more importantly is intended as a media of da'wah for the sake of Islam as an effort of a calligrapher to draw closer to Allah Almighty, God Create everything in vain. Verily Allah is Most Beautiful loves beauty. Subhanallah. ***

\section{REFERENCES}

[1] E.V. Indraswari, "Ibnu Muqlah (887-940)" 2015. [Online]. Retrieved from: http://www.pesantrenkaligrafipskq.com/2015/04/sejarah-peletakdasar-kaligrafi-ibnu.html (5 Mei 2018).

[2] D.A.R. Sirojuddin, Seni Kaligrafi Islam. Bandung: Remaja Rosdakarya, 2000

[3] M. Susanto, Diksi Rupa: Kumpulan Istilah dan Gerakan Seni Rupa. Yogyakarta: DictiArt Lab \& Djagad Art House, 2011.

[4] A.A. Ahmad, Ragam Karakter Kaligrafi Islam: Mengupas Tuntas Kaligrafi Ekspresi. Jakarta: Amzah, 2009.

[5] Azakaligrafi, "Lima Langkah Praktis Proses Berkarya Abd. Aziz Ahmad" 2014. [Online]. Retrieved from: https://azakaligrafi.wordpress.com/2014/09/06/proses-berkarya-2/ (3 May 2018) 